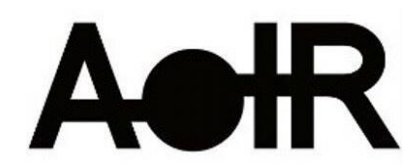

Selected Papers of \#AoIR2021:

The 22nd Annual Conference of the

Association of Internet Researchers

Virtual Event / 13-16 Oct 2021

\title{
MEMEING AGAINST MAINSTREAM. AN ANALYSIS OF DANK MEMES AND THE PICTORIAL (COUNTER-)PRACTICES OF MEME CULTURE
}

\author{
Kevin Pauliks \\ University of Marburg
}

Memes are commonly associated with funny pictures on the internet that can be shared with friends and family on popular platforms like Facebook, Instagram, and Twitter. Every day, millions of people view, create, and circulate memes on these platforms. Marketers rapidly jumped on the bandwagon to promote products and brands through the practice of memeing. For example, the meme Grumpy Cat is not just independent user-generated content, but "a whole business" (Csordás et al. 2017: 247) and therefore a brand in itself. When Grumpy Cat was born and evolved into a well-known meme in 2012, memes in general became popular worldwide (see Google Trends for the term "meme" between 2004 to 2021). The interest in memes steadily rose from this year on, peaking in 2020, when the COVID-19 pandemic started, spurring many popular memes on social media.

This mainstreamization of memes happened much to the dismay of users on platforms like 4chan, Reddit, and Tumblr, where most memes originate from. The self-proclaimed 'meme lords' on these platforms try to preserve their subculture from outsiders, who they stigmatize as 'normies' that perhaps view and share mainstream memes, but do not actually understand the practice of memeing, i.e. how to create and spread memes properly. This distinction is enacted as part of specific boundary work to maintain the exclusiveness of meme culture (Literat/van den Berg 2019: 239f.). A strategy of this boundary work is to implement ironic markers in memes that need contextual knowledge to be deciphered and therefore act as "a communicative 'trap' for outsiders" (Gal/Kampf/Shifman 2020: 2). As a result, a whole new genre of ironic memes emerged, known on these platforms as 'dank memes' (Granata 2019), which can be broadly defined as meme-critical internet memes that reflect upon the practice of memeing. In other words, dank memes are a particular form of vernacular criticism, which aims at mainstream memes from the perspective of meme culture.

So far, vernacular criticism is highly underexplored, especially in regard to memes (Literat/van den Berg 2019: 233). While Literat and van den Berg focus on discursive critique in the form of comments, I intend to emphasize the pictorial practices of criticism

Suggested Citation (APA): Pauliks, K. (2021, October). Memeing against Mainstream. An Analysis of Dank Memes and the Pictorial (Counter-)Practices of Meme Culture. Paper presented at AolR 2021: The 22nd Annual Conference of the Association of Internet Researchers. Virtual Event: AolR. Retrieved from http://spir.aoir.org. 
that are used in memeing. Dank memes are visual media after all, and should be considered as such when analyzing their practices. Most memes are, in fact, digital pictures about other pictures or what W. J. T. Mitchell (2005: 6) calls "metapictures." However, dank memes are not just addressing other pictures, but also memes and the practice of memeing itself. The research question I want to address is: how are dank memes used for reclaiming the independent media practice of memeing from mainstream and marketing culture, to counteract the popularization and commercialization of memes?

To answer this research question, I would like to propose an approach, which we call "picture practice analysis" (Pauliks/Ruchatz forthcoming), a method designed to reconstruct pictorial practices through analyzing digital pictures themselves. This methodology combines media philosophy, a philosophy of media reflecting on media (Engell 2011), with a praxeological perspective (Reckwitz 2002). It is particularly suited to analyze metapictures such as dank memes, which reflect on their own mediality and practices (Mitchell 2006: 210). Pictorial practices can be deduced from (meta)pictures, because "human actions are turned into images" (Stiegler 2018: 5). Following Ryle (1946: 4), these practices produce knowledge; in this case, knowledge about memeing, distinctly constituted of "knowing that" a meme references other memes in relation to "knowing how" a meme is created and spread on the internet.

My analysis is based on the meta-meme Memes Then, Memes Now, which compares mainstream memes to dank memes. Examples can be found on the subreddit $\mathrm{r} /$ dankmemes, a community dedicated to posting and discussing dank memes. My observations suggest, on the one hand, that dank memes take a stand against image macros, which are commonly known as 'memes,' and which were already declared dead in the wake of their mainstreamization (Milner 2016: 43). Dank memes critically reflect on the aesthetic standards of image macros: incoherent fonts and misspelled captions are used to contrast the classic Impact font. Templates are deliberately deformed by cropping the frame or 'deep frying' the image with as many filters as possible. These picture practices of reappropriating reappropriations serve the particular purpose of reclaiming memes by making them "Internet Ugly" (Douglas 2014), hence unusable for mainstream and marketing. On the other hand, the meta-meme criticizes dank memes for their nonsensical and forced ugly aesthetic, which function merely as shibboleths to meme culture without deeper meaning. With this visual vernacular criticism, user theorize and historize what is new and 'dank' or old and 'normie,' constantly (con)testing and pushing the boundaries of meme culture. Consequently, Memes Then, Memes Now reflects on memeing by knowing what make memes mainstream and knowing how specific counter-practices can be applied against this mainstreamization to make memeing an independent media practice once again.

Learning about these pictorial practices is important to understand how meme culture is affecting the mainstream. Ironically, dank memes are popular enough now to be considered a cultural currency (Literat/van den Berg 2019: 237). Examples such as the GameStop short squeeze and high-priced NFT sales demonstrate that this cultural currency has an actual impact on the economic currency of mainstream and marketing culture. 


\section{References}

Csordás, T. et al. (2017): User-Generated Internet Memes as Advertising Vehicles. Visual Narratives as Special Consumer Information Sources and Consumer Tribe Integrators. In G. Siegert, M. B. Rimscha, S. Grubenmann (Eds.): Commercial Communication in the Digital Age. Berlin, Boston: De Gruyter, pp. 247-265.

Douglas, N. (2014): It's Supposed to Look Like Shit: The Internet Ugly Aesthetic. In Journal of Visual Culture 13 (3), pp. 314-339.

Engell, L. (2011): Ontogenetic Machinery. In Radical Philosophy (169), pp. 10-12.

Gal, N./Kampf, Z./Shifman, L. (2020): SRSLY?? A Typology of Online Ironic Markers. In Information, Communication \& Society, pp. 1-18. URL:

https://doi.org/10.1080/1369118X.2020.1814380 (last checked 7/6/2021).

Granata, Y. (2019): Meme Dankness: Floating Glittery Trash for an Economic Heresy. In A. Bown, D. Bristow (Eds.): Post Memes. Seizing the Memes of Production. Santa Barbara: punctum books, pp. 251-275.

Literat, I./van den Berg, S. (2019): Buy Memes Low, Sell Memes High: Vernacular Criticism and Collective Negotiations of Value on Reddit's MemeEconomy. In Information, Communication \& Society 22 (2), pp. 232-249.

Milner, R. M. (2016): The World Made Meme. Public Conversations and Participatory Media. Cambridge: The MIT Press.

Mitchell, W. J. T. (2005): What Do Pictures Want? The Lives and Loves of Images. Chicago/London: University of Chicago Press.

Pauliks, K./Ruchatz, J. (forthcoming): Towards a Praxeological Media Philosophy of the Digital Image. Theorizing Pictorial Picture Critique in Social Media. In International Journal for Digital Art History.

Reckwitz, A. (2002): Toward a Theory of Social Practices. A Development in Culturalist Theorizing. In European Journal of Social Theory 5 (2), pp. 243-263.

Ryle, G. (1946): Knowing How and Knowing That. In Proceedings of the Aristotelian Society 46, pp. 1-16.

Stiegler, B. (2018): How to Do Things with Photographs. Towards a Praxeology of Photography. In M. Neumüller (Ed.): The Routledge Companion to Photography and Visual Culture. New York/London: Routledge, pp. 4-13. 